\title{
SCIENTIFIC REP RTS OPEN Author Correction: The interplay of social group biases in social threat learning
}

\section{Armita Golkar ${ }^{1,2} \&$ Andreas Olsson ${ }^{1}$}

Correction to: Scientific Reports https://doi.org/10.1038/s41598-017-07522-z, published online 09 August 2017

The Acknowledgements section in this Article is incomplete.

"This research was supported by an Independent Starting Grant (284366; ELSI) from the European Research Council to A. Olsson and a post-doctoral grant from the Swedish Science foundations (2015-00312) to A. Golkar."

should read:

"This research was supported by an Independent Starting Grant (284366; ELSI) from the European Research Council, and the Knut and Alice Wallenberg Foundation (KAW 2014.0237) to A. Olsson and a post-doctoral grant from the Swedish Science foundations (2015-00312) to A. Golkar."

(i) Open Access This article is licensed under a Creative Commons Attribution 4.0 International License, which permits use, sharing, adaptation, distribution and reproduction in any medium or format, as long as you give appropriate credit to the original author(s) and the source, provide a link to the Creative Commons license, and indicate if changes were made. The images or other third party material in this article are included in the article's Creative Commons license, unless indicated otherwise in a credit line to the material. If material is not included in the article's Creative Commons license and your intended use is not permitted by statutory regulation or exceeds the permitted use, you will need to obtain permission directly from the copyright holder. To view a copy of this license, visit http://creativecommons.org/licenses/by/4.0/.

(c) The Author(s) 2018 